\title{
Youth Tourism in the Russian Province: Study of the Possibilities for Local Tourist Market Development
}

\author{
Elena N. Koroleva1 \\ Olga V. Semenchuk ${ }^{2}$ \\ 1. Samara State University of Economics, Russia, 443090, Samara, Sovetskoi Armii Street, 141 \\ 2. Samara State University of Economics, Russia, 443090, Samara, Sovetskoi Armii Street, 141 \\ Correspondence: Svetlana I. Ashmarina, Samara State University of Economics, 443090, Russia \\ Samara, Sovetskoi Armii Street 141, Email: korol388@mail.ru
}

\section{Doi:10.5901/mjss.2015.v6n6s3p403}

\section{Abstract}

According to forecasts of the World tourism organization (UNWTO) by 2020 Russia will be able to enter the first ten countries which are assessed not only by the number of tourists crossing the border, but also by tourists reception that is more important. Specified forecasts do not consider potential volumes of internal tourism services which are formed in Russian regional (local) tourist markets. In this regard, scientific research of potential of youth tourism development is extremely urgent in Russian regions: 1) now youth tourism develops very quickly and will considerably influence development prospects of internal tourism in Russia; 2) youth tourism can be positioned as a segment of global international tourism as travelling youth today is an international tourist in the future. The research objective is to confirm a hypothesis that youth tourism in Russia is formed as an independent kind, and it has prospects and gives an impulse to develop regional (local) tourist markets. Research is based on empirical data obtained by means of an sociological poll (questioning) of rural municipal areas residents and small cities of the Samara region that represent typical settlements of Russian province. Special attention is paid to results interpretation of youth questioning in rural municipal area Sergiyevskii. As a result of research various approaches to youth tourism definition are identified, various sections (aspects) of subjective factors that form youth attitude to tourism of Russian province are revealed; diagnostics of youth tourist services structure is implemented. Research results are addressed to public and municipal administration in Russian regions, to travel business organizations, public youth organizations.

Keywords: youth tourism, internal tourism, local tourist market, small city, rural municipal area.

\section{Introduction}

\subsection{Problem relevance}

The view over the prospects of Russian tourism regarding features of a present stage of economic development allows noting what speed of tourist industry entry into the market led this sphere of Russian economy to a number of high rates developing economies. And economic crisis didn't considerably influence development of this sphere of Russian tourist business. So, in 2013 in the Russian Federation the number of tourists who were served by tourist companies, increased by 2,3 times in comparison with 2005 (Regions of Russia, Open data). The statistical analysis shows that the vector of Russian tourist flows is focused not on internal, but on external trips. So, dynamics of number of domestic tourists trips across Russia lags behind considerably the dynamics of their trip abroad.

It was promoted by a number of objective prerequisites and retrospective factors, among which one of the major factors is collapse of the USSR. If in Soviet Union times foreign tourism was available only for some part of the population, and generally because of political, not economic reasons, after transformations happened, all residents of the country had an opportunity to travel to other countries. Collapse of the country resulted that the most part of the Black Sea coast of the Caucasus joined Georgia and Ukraine, a resort area of the Baltic coast joined Baltic countries. As a result, tourism direction significantly changed, it became mainly exit, and a high level of tourist business development made tourism prestigious for foreign countries.

In this regard, scientific research of prospects of internal tourism development and potential new forms of its organization in terms of regional markets is actual. 


\subsection{Research analysis and a brief literature review}

\subsubsection{Regional tourist market}

The following works of Russian scientists are specified, the most important for us in terms of considered issue are the role of recreational factors of regional tourist market formation, "tourist destination" (Preobrazhensky, 1982), identification of the regional tourist market (Zorin \& Kvartalnov, 2000), research of its features and structure (Frolova, 2011). Regional specialization of tourist services market is carried out within spatial borders that coincide with structure of administrativeterritorial division of the country. The Russian Federation unites 85 subjects (republics, areas). The regional tourist market in Russia is often considered as a market of Russian Federation subject.

Regional market of tourist services is characterized by such phenomenon as an individual profile of tourist destination. Tourist destination defines appeal of tourist service and creates tourist motivation. Regional market is formed under the influence of such factors as a geographical position, a landscape, bioclimatic and ecological characteristics of territorial units and their historical and cultural parameters.

The regional market of tourist services can be considered as set of three components (segments): outbound, inbound and local (in the region). The local segment is a low budget internal tourism, the demand of which includes regional citizens with low earnings to whom outbound tourism is inaccessible.

\subsubsection{Youth travel}

In spite of the fact that tourism and travelling have a long history, youth travel started to develop only in the last decades. The history of youth travel research is even shorter. Since 1980s in the works (Cohen, 1973; Vogt, 1976) some kinds of activity are considered that are made by youth during rest and travel. In later research that relats to the 1990-2000s (Seekings, 1998; Pastor, 1991; Horak \& Weber, 2000), an attempt to define youth travel as a special segment in an international market structure of tourist services is made.

A lot of approaches to define youth travel are typical for research of this stage. There is no an independent classification sign that allows to allocate youth travel and its types (forms) in a separate group. As a rule, youth travel gets into the group that is allocated according to age of participants: children, youth travel, tourism of middle age people, tourism of elderly people (Babkin, 2008). The impossibility to apply demographic categories is connected with that "youth travel" is not a certain age, but special style and travel nature. And it is connected with special motivation. Most researchers, specify that an essential (motivational) sign is the most important sign of tourism types classification (Gorgoz \& Nabokov, 2009).

Foreign authors and organizations, as a rule, connect youth travel with educational and informative motivation and position it in an international market structure of tourist services (Foris D., Nicolau \& Foris T., 2014; WYSE Travel Confederation, 2015). So, WYSE Travel Confederation supposes that youth travel is an independent travel undertaken by people aged from 16 to 29 out of borders of constant residence place for less than a year time period, the main objective of which is a desire to get acquainted with other cultures, to increase life experience, to use educational opportunities abroad.

Unlike them Russian authors and organizations refer exact kinds of youth activity to youth travel concept: specialized camps, excursions, tourist competitions and actions, extreme kinds of activity in natural environment (mountaineering, rock-climbing, sports orientation, rafting, etc.) (Young Russia, 2009) and Russian authors also position youth travel in structure of domestic tourist market. Research of youth travel development in local markets with sociological methods application is one -of-a-kind (Koroleva \& Semenchuk, 2013).

\section{Methods}

There is a big variety of research methods of tourist markets; exact method application depends on a research object, the purpose and available information.

In this research use of social research methods is expedient because of following reasons:

1) official statistical information which is available in Russia does not allow to carry out regional markets analysis of tourist services in full. This remark belongs to a local segment;

2) tourist demand and a tourist product formation on a local market has a special nature in youth environment.

Object. Sociological survey was conducted in small towns and in rural municipal areas of Samara region (in brackets population of the cities and areas on 01.01.2014, is specified by Open data): 

people).

small towns: Bezenchuk (22507 people) and Kinel (56191 persons);

rural municipal areas: Kinel-Cherkasskii (45822 people), Sergiyevskii (46070 people) and Stavropolskii (63273

As the main method of social research occasional non-repeated sample was applied that provided a high level of representativeness.

4330 people took part in a poll, 2063 people are from towns, 1767 people are from rural areas Kinel-Cherkasskii and Stavropolskii. In a rural area Sergiyevskii special research was conducted. The survey was conducted only among youth: 500 people were questioned in age limits from 16 to 34 .

For a questionnaire special application form was made, the questions of which were subdivided into two blocks. Questions of the first block allowed to receive respondent characteristics: sex, age, marital status, education, social status, nationality. Questions of the second block were presented by the following groups: 2 questions, answers on which allow to assess possibility of youth to get tourist services; 10 questions, answers on which give an idea about a structure of tourist services that youth prefers; 6 questions, answers on which allow to implement diagnostics of youth travel development on definite territory.

On all territories the chosen objects of a sociological poll met imposed requirements: they are defined by spatial limitation and functional orientation, by temporary limitation and possibility of quantity measurements.

The method that was applied to process results is a method of simple and difficult grouping. It allowed to carry out a detailed analysis of opportunity of local tourist services market development in Samara region of the Russian Federation.

\section{Results}

\subsection{Prospects of local tourist market development}

Studying of statistical data in Samara region allowed to make the following assessment: in 2012 tourist packages to foreign countries made $68,9 \%$ from all tourist products that were realized by the population.

This conclusion was confirmed by the results of social research: about half of respondents that position themselves as people of average life level, are able to afford trips to foreign countries. Differentiation of urban and rural population is revealed according to possibility to purchase tourist packages to foreign countries. About $40 \%$ of respondents from small towns are able to afford trips to foreign countries that cost 30 thousand rubles and more.

Among villagers only about $15 \%$ of respondents can afford such trips ( although $62 \%$ of respondents referred themselves to a group"of an average life level").

Thus, though an outbound market segment of tourist services in the region is the most developed now, inbound tourism will be relevant for the population of the Samara region, especially for citizens of rural areas.

In the course of studying of development prospects of the local tourist markets in the Samara region, it was revealed that allocation of such tourist industry direction as youth travel is quite justified since tourist demand formation and a tourist product are very special in youth environment.

\subsection{Results of youth questioning in rural area Sergiyevskii}

Gender participants structure of a poll in the rural area Sergiyevskii is the following: $50,6 \%$ made men and $49,4 \%$ made women. As a result of age structure analysis all respondents were distributed into four groups (approximately equal in number). An age group 20 - 24 years got a small advantage which specific weight made $28 \%$. A little more than a half of respondents $(50,6 \%)$ were not married. Less than a half of respondents had secondary vocational education (41\%), but the share of people who have a higher education is rather high, $24 \%$. Among questioned youth there were representatives of all social groups. More than one fourth part of all questioned made workers (28\%). The share of students is high $23,4 \%$. Considerable part of respondents, $82,4 \%$ are Russian. Other nationalities made $17,6 \%$ of a total number. The structure of respondents gave the chance to assess sample as representative.

Answers to a question how municipal area youth prefers to spend holidays (Figure 1) are quite interesting. 


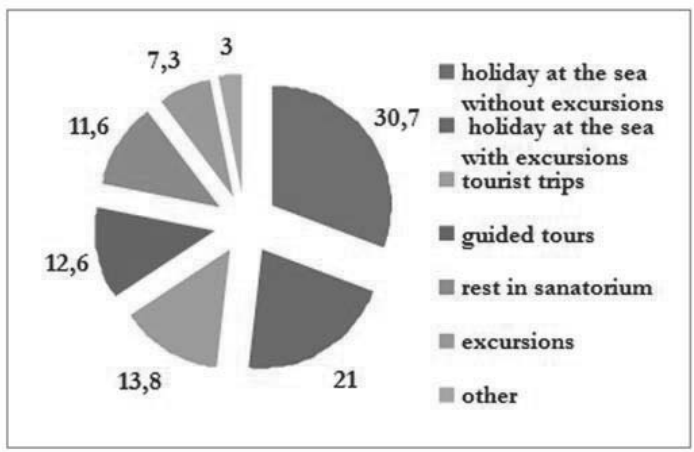

Figure 1. The structure of answers to a question "What is more preferable for you on holiday?"

More than a half of all respondents $(51,7 \%)$ prefer to have a rest by the sea (either with excursions, or without them). More than a quarter of all respondents $(26,4 \%)$ spend holidays taking tourist trips and tourist hikes. A small percent of participants (3\%) prefers to spend holidays at home (for example, by the river).

A possible form of youth travel organization in the region is weekend tourism, (Figure 2).

It was revealed that about $40 \%$ of respondents spend days off at home, about $30 \%$ of respondents go somewhere to have picnic, only every sixth respondent $(16,0 \%)$ is engaged in active sports outdoors at the weekend.

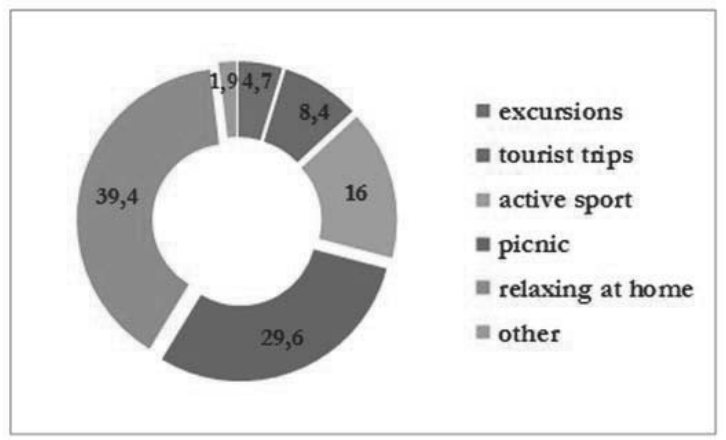

Figure 2. The structure of answers to a question "What is more preferable for you at the weekend (free time)?"

Nevertheless, tourist services are demanded by most of respondents. We have made such conclusion taking into account a question "Have you ever taken tourist trips?". Two of three respondents sometimes took trips (68,3\%).

Annually only $16,9 \%$ of respondents use tourist services, $15 \%$ never use them.

Results of obtained data analysis showed that about a half of respondents prefer to have rest with a family $(46,8 \%)$, other half $(44,2 \%)$ prefers to have rest in a youth company with friends. Only $9 \%$ of all respondents chose an individual rest.

Answering a question about travel cost availability more than a half of respondents (58,3\%) mentioned a sum ranging from 5 to 10 thousand rubles per person (21,9\% and 36,4\%), three quarters of respondents position themselves as people with an average income. Assessment of other answers to a question about travel cost availability allows to draw a conclusion that for youth the cost of a tourist product (for example, a trip) should not exceed 15 thousand rubles per person.

For directions development of youth travel structure of answers to a question "What attracts youth in travelling?" seems very interesting (Figure 3). 


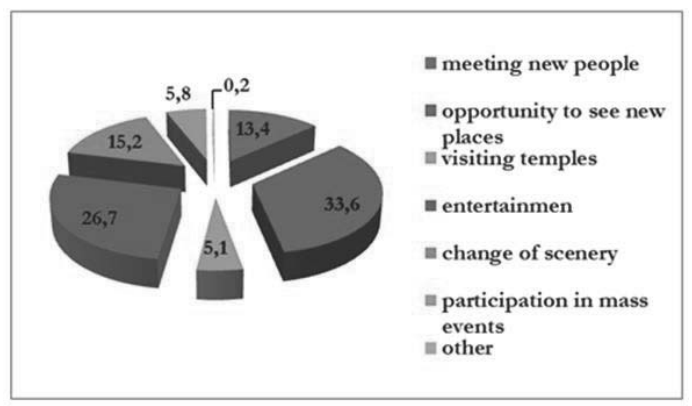

Figure 3. The structure of answers to a question "What attracts you in travelling?"

Opportunity to see new places attracts one third of respondents in travelling (33,6\%), opportunity to have a good time attracts a little more than a quarter (26,7\%). Scenery change and acquaintance with new people attract $28,6 \%$ of respondents ( $15,2 \%$ and $13,4 \%)$.

Culture level increase and spirituality development turned out to be unattractive purposes for respondents. Travel is attractive only for $5,8 \%$ by the opportunity to participate in interesting mass events (holidays, festivals or competitions) and only for $5,1 \%$ of respondents pilgrimage tourism is interesting. In this regard event and pilgrimage tourism types development has a high potential taking into account features of local tourist services market. Providing specified types of tourist services with corresponding advertizing and further marketing promotion can stimulate demand among youth.

Reasons analysis which prevent respondents from travelling (Figure 4) seems rather interesting.

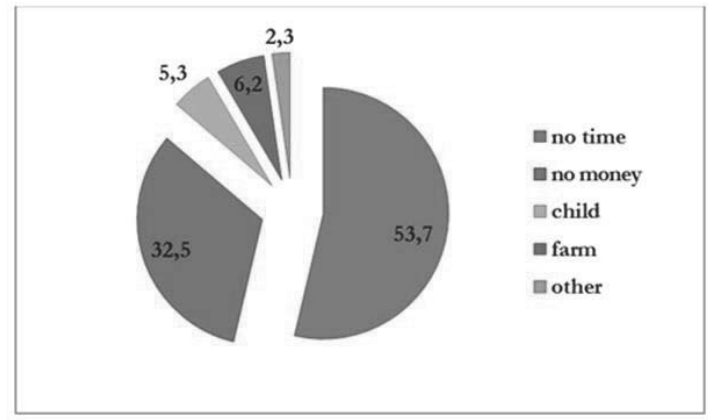

Figure 4. Structure of answers to a question: "What prevents you from travelling?"

More than a half of young people $(53,7 \%)$ pointed such reason as a lack of time. Also youth doesn't have time for expensive trips (32,5\%). High youth employment does not allow to spend a lot of time having rest (leisure), and young people welfare does not allow them to get an expensive tourist product. Therefore, local resources availability encourages to develop tourist business and to form demand for specific tourist services in youth environment.

Respondents opinions grouping, given in answers to a question "It is possible to consider Sergiyevskii area as a territory for youth tourist directions development ?" allowed to create an assessment of a municipal area Sergiyevskii as a territory of youth travel development.

So, according to poll results, only every third respondent considers that now a municipal area is a territory for youth travel development. About a half of respondents $(49,9 \%)$ consider that the area can be positioned as a territory of youth tourist directions development only in a long term perspective. Specific weight of those young people who do not see possibility of territory tourism development (19\%) is rather high.

Judging by objective assessments, the territory of Sergiyevskii area has all groups of potential tourist resources: health-improving, informative and sports. On the territory of the area there are unique nature sanctuaries of national and local value. They are: Brimstone Lake, Sernovodskaya Cave, Blue Lake, Mount Sheehan (Komrakov, Tatarenkov \& Gold, 
2011). In this regard to respondents it was offered to call tourist products which would be interesting to youth. Only one third of all respondents answered this question. As a tourist product about a half $(43,6 \%)$ called the route connected with the Blue Lake, $11,5 \%$ of respondents called the route connected with Mount Sheehan. Other respondents offered: the Brimstone Lake, mountain tours, caves, riverside Sok, Orthodox churches. Questioning did not reveal any essentially new tourist routes in the municipal area which would be interesting to youth.

Nevertheless, respondents believe that on the territory of a municipal area different types of tourist services can be popular. About a half of all respondents (45,6\%) consider that on the territory of the area such extreme kinds of activity can develop as sports tourism, sports orientation, hand gliding, diving, etc.; $22,7 \%$ of respondents consider that it is necessary to pay more attention to tourist competitions and events, and $21,7 \%$ suggest paying attention to various excursions. Thematic camps creation isn't interesting for youth judging by respondents answers.

The answer to a question "what elements of youth travel infrastructure (Figure 5) need to develop on the territory of the municipal area first of all?" is very inportant.

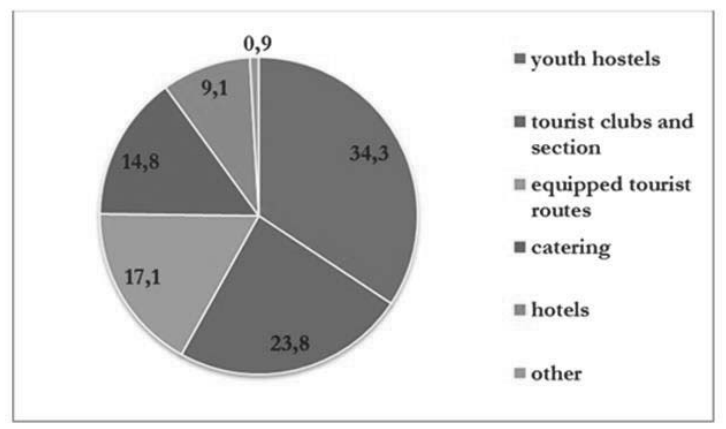

Figure 5. Structure of answers to a question: "What elements of youth travel infrastructure on the territory of your area are necessary to develop first of all?"

Every third respondent $(34,3 \%)$ considers that first of all it is necessary to develop youth camp sites, and also tourist clubs and special classes (23,8\%). $17,1 \%$ of respondents think that it's necessary to develop equipped tourist routes. $14,8 \%$ of respondents indicates that public catering development is very important.

\section{Conclusion}

Research results confirmed the hypothesis: youth travel in Russia is formed as an independent kind and has many opportunities for local tourist markets development.

Advertising of youth travel on the territory of each Russian region has to be opposed to aggressive marketing policy of the companies advertizing foreign tourism. Lack of information about developed local tourist products, leads to absence of demand in the region.

In this regard much attention should be paid to support of organized youth travel forms. In modern conditions youth needs social contacts (communication, interaction), and opportunity to satisfy them, for example, on the basis of new technologies of network interaction. It is necessary to consider a role and social opportunities of tourist clubs, to develop them as a social and network consumption form for young people.

The first step in stimulation of youth travel development on the territory of the Samara region is development of tourist infrastructure objects (youth camp sites, hotels, organized tourist routes).

Each municipal area of the Samara region has to create and develop a place of interest on the territory, a destination that will attract tourists with specific natural and recreational resources, sights, historical and cultural heritage. Local feature gives to a destination its special appealing, and specific (including youth) tourist products will be unique, special and distinguished.

As the recommendation we will conclude that on the regional level it is expedient to continue similar research, and choose "unique" municipal areas in each region of the Russian Federation. It will allow to implement more accurate assessment of the situation and to define features, priorities and prospects of youth travel development on local segments of regional tourist markets in Russia. 


\section{References}

Babkin, V.A. (2008). Special types of tourism. [Online] Available: http://www.tourlib.net/books_tourism/babkin01.htm

Cohen, E. (1973). Nomads from Affluence: Notes on the Phenomenon of Drifter-Tourism, International Journal of Comparative Sociology 14 (1-2), pp. 89-103.

Concept of development of of Youth Tourism. Young Russia/ (2009). [Online] Available: http://rumol.ru/foto/tagan/docs/turizm/1.htm

Foris, D., Nicolau, C., \& Foris, T. (2014). Future trends on the spot in international tourism - modern youth educational tourism. European Scientific Journal, May 2014 /SPECIAL/ edition, 526-532.

Frolova, M. V. (2011). Features of formation of the regional market of tourist services. Actual problems of Economics and law. 4. pp.230234.

Gorgoz, O.V. \& Nabokov, V.I. (2009). Development of regional tourism industry in the context of globalization (on the example of the Khanty-Mansiysk Autonomous Okrug - Ugra). Kurgan: LLC "Dummy".

Horak, S. \& Weber, S. (2000). Youth Tourism in Europe: Problems and Prospect, Tourism Recreation Research.

Komrakov, A. Tatarenkov, S. \& Gold, E. (2011). The Land Of Samara. The tourism potential of the Samara region. Samara: "Pushkin square".

Koroleva, E.N. \& Semenchuk, O.V. (2013). Youth tourism: an innovative approach to the development of the regional tourist market. Samara. Vestnik of Samara state University of Economics. 3. pp. 37-41.

Pastor, J.M. (1991). The Nature of Youth Tourism: Motivations, characteristics and requirements. Paper presented at the WTO International Conference on Youth Tourism. New Delhi. India.

Preobrazhensky, B.C. (1982). Geography of recreational systems of the USSR. Moscow: Progress.

Regions of Russia. Statistical Yearbook. (2013). Open data. [Online] Available: http://www.gks.rul.

San Diego Declaration on Youth, Student and Educational Travel. WYSE Travel Confederation. [Online] Available: http://www.wysetc.org.

Seekings, J. (1998). The youth travel market, Travel \& Tourism Analyst. Vol 5. pp.37-55.

Vogt, J.W. (1976). Wandering: Youth and Travel Behaviour, Annals of Tourism Research 4 (1). pp.25-41.

Zorin, I.V. \& Kvartalnov V.A. (2000). Encyclopedia of tourism. Handbook. Moskow: Finance and statistics. 